Original Research Paper

\title{
Haematological Status for Selected Pig Breeds
}

\author{
${ }^{1}$ Janka Kotosová, ${ }^{1}$ Janka Poráčová, ${ }^{2}$ Ladislav Vaško, ${ }^{1}$ Marta Mydlárová Blaščáková and ${ }^{2}$ Janka Vašková \\ ${ }^{I}$ Department of Biology, Faculty of Humanities and Natural Science, \\ University of Prešov, 17th November Street 1, 081 16 Presov, Slovak Republic, Slovak \\ ${ }^{2}$ Department of Medical and Clinical Biochemistry, Faculty of Medicine, Pavol Jozef Šafárik University, \\ Tr. SNP 1, 04066 Kosice, Slovak Republic, Slovak
}

Article history

Received: 18-09-2014

Revised: 26-11-2014

Accepted: 17-12-2014

Corresponding Author: Janka Vašková

Department of Medical and

Clinical Biochemistry,

Faculty of Medicine, P.J. Šafárik

University in Košice,

Tr. SNP 1, 04066 Košice,

Slovak Republic, Slovak

Email: janka.vaskova@upjs.sk

\begin{abstract}
Changes which are constantly brought by the transformation of our agriculture, as well as the effort to be involved in the EU market economy and change priorities in various areas of our economy. They can be summarized in the quality, productive health and economy. Blood count does not only change in pigs with age, but it also depends on the method of pig housing, feed and thermal regime. Changes in the haematological status of the organism eventually affects the quality of meat. This study focuses on the hematological status of selected pig breeds including Yorkshire, which is reared in conventional farming and Mangalitsa, which is reared as ecologicallive stock, including more specific characteristics of the studied breeds. The values observed between breeds differ in higher numbers regarding white blood cells and platelets which were found in the Yorkshire breed. In relation to the seasons, we found a gradual increase in values from spring to autumn. Observed differences in the haematological profile can be used in the assessment of animal health in relation to physiological changes in the internal environment during the various stages of life concerning livestock breeding.
\end{abstract}

Keywords: Hematological Status, Yorkshire, Mangalitsa, Conventional Farming, Ecological Livestock

\section{Introduction}

The Common Agricultural Policy as it is set at present, causes immense declines in numbers of livestock and it also affects rural employment. In recent years, in the rearing of pig sin Slovaki at here have been many negative phenomena, consisting in the decrease in the total number of pigs (boars) and sows, which is increasing the cost of compound feed as well as reduced prices for farmers to slaughter pigs (Tančin, 2013). The situation in the rearing of pig sat the moment is almost at the same level as it was a century ago, however, at that time there were reared more pigs than the current status. In early 2011, the rearing of pigs suffered the worst period since joining the EU, when prices fell far below the cost of production. The greatest impact on prices was the occurrence of dioxins in meat, found in Germany, where there was pressure due to the suspension of exports to several countries outside the EU. At that time the price dropped below $1.0 €$ per $\mathrm{kg}$ of body weight. This condition is also reflected in the actual development of the Breeder's-breeding. The deep crisis in the rearing of pigs was reflected by a further decrease in the total number of pigs, a decline in the number of sows, despite of major initiative of Association of Pig Breeder sin
Slovakia-Cooperative (APBS-C) and its various activities for pig farmers. A similar situation was also reflected in the decline of a number of breeding and reproductive holdings. Many farmers have stopped mating sows and began to liquid ate the whole pig holdings even though it was not to a large extent. Pigs are primarily reared for the production of pork, which is still placed among the most consumed meats in Slovakia. After the holding of cattle, it makes up about $50 \%$ of the annual consumption of meat per inhabitant and it is a long tradition. The main products are meat with a distinctive taste and important biological substances including bacon and lard and they also part of diet and the lard is also used in the pharmaceutical industry.

Today's breeds of pigs in the world have been subjected by long stages of development, while the influence of the use of optimal methods of breeding, intensive selection and improving the conditions of nutrition and housing reached the level of specialized bred types (reproductive characteristics, fattening and conformation). Breeds of pigs can be divided either by body size e.g., small, medium and large, or according to color including-white, black, red and spotted (Ochodnícky and Poltársky, 2003). According to 
Fazekašová and Poráčová (1999) cultural breeds of pigs are divided into the following groups: Curly-haired pigs-Mangalitza (blond Yugoslav Mangalitza, Hungarian Mangalitza, it island types of breeds), white-haired pigsthe most important economic group, which is further divided according to structural properties and particularly the shape of the ears into subgroups, red-haired pigsDuroc, Minnesota, etc., they belong to the meat and lard type of pigs, black and white breeds of pigs-Cornwall, Moravia, Berkshire etc.., black-spotted breeds of pigsPietran, Slovak black-spotted pig, etc.. Striped black and white pig breeds-the English saddle pig, Hampshire. Breeding of Straight ear pigs started in Slovakia around 1848 in rougher conditions. The breed was well adapted to those conditions. In southern Slovakia it extended to Mangalitza, which was maintained until 1961 it thrives concerning extensive breeding. Imports from England, Germany and Poland began after 1850, when crosses of a Polish pig with a Yorkshire were brought to Slovakia. It was a period with the most varied combinations of crossing according to the tastes and times. An improved Polish Yorkshire was imported from 1909-1911. A Slovak white pig was crossed with a Yorkshire, which was also bred as a pure breed (Lojda et al., 2008). In the recent times, improved types of white pigs were unified to Slovak White Improved breed (Sambraus, 2006).

Meat production is the result of a number of morphological and physiological properties of the organism, which depend on genetic factors and environmental factors, particularly related to food. Slaughter value of an animal is assessed by several indicators. The general principle is that pigs are in good condition regarding health because only healthy pigs are capable of delivering use fullness for a long time. In each breed there are pigs with a good and poor stature and because of this it has an impact on an individual's ability to adapt to the environment and resist adverse effects. Pigs have the ability to store fat, it's the result of a changed function regarding the endocrine glands after completion of physical development, which reduces the conversion of substances and oxidation processes. An important requirement in the rearing of pigs should be to ensure conditions of life, which would allow full use of their internal capabilities for efficient and quality production. In addition to corresponding nutrition and the adequate care of pigs, an important roleis played by the housing system and hygiene as they affect their standard of welfare (Barnett et al., 2001; Mlynek et al., 2012).

Useful characteristics of the animal are formed during growth. Knowing the biological context helps to create ideas about processes in the beginning with progress or completion involved in the production of livestock, or it is directly determined. The effects of the environment as well as the effect of stress related to a given environment on the individual which can affect and modify the hematological and biochemical status of the organism (Doubek, 2007), which eventually affects all factors which help guarantee the preservation of taste, nutritional, hygienic and technological indicators which collectively form meat quality. The aim of this work was to characterize and compare the haematological parameters of the breed Yorkshire from conventional breeding and Mangalitza from organic farming in relation to seasons and breed animals.

\section{Materials and Methods}

Blood samples from pigs including Yorkshire and Mangalitza were collected at the same time of day, in the morning from two farms. Farm Agrozoran Michal'any in the district of Trebišov in the villages of Luhyňa and Michal'any which lie in the southwestern part of the Eastern low land sat the foot of the Zemplin Hills. Conventional farming for the Yorkshire breed and organic stock farming for Mangalitza. Mangalitza are kept in the wild in a pasture with a shelter and bedding straw throughout the year even in winter. They have access to nursing piglets, ČOS (Časný Odstav Selat, Early weaning piglets) is given to piglets and fattening pigs are fed with a VUL (Výkrm ošípaných lyzinovaný, Fattening pigs lysine). Eco Farm of Ing. Michael Lacko is located in the village of Velaty near the farm Agrozoran Mangalitza are similar to the previous farm as they are reared in a pasture and fed feed in the morning, throughout the day they have access to water and food. The shelter is lined with straw and it is cleaned regularly.

Blood was collected from the jugular vein into tubes $\mathrm{K}_{3}$ EDTA each time from 15 individuals of Mangalitza and 15 individuals of Yorkshire from conventional farming around the same age and all pigs were in good physical condition. Sampling was realized three times. The first time was in the spring in the month of May and the other two in other seasons: Summer-in August and autumn-in November. Analysis of White Blood Cells (WBC), Red Blood Cells (RBC), Hemoglobin (HgB), Hematocrit (Htc), Platelets (Plt) were transferred using the hematology analyzer Beckman COULTER ${ }^{\circledR} A c \cdot$ Tdiff $^{\mathrm{TM}}$. For statistical evaluation, we used the non-parametric analysis of variance of Kruskal Wallisstest, as well as to compare two types in the same collection period the nonparametric Mann Whitney Utest was used.

\section{Results}

In the Yorkshire breed there in the measured values of the White Blood Cells (WBC) in the spring collection significant differences were not found in comparison with the values from summer and autumn collection. The average value of WBC in the spring sampling (Fig. 1) was higher than the average value of WBC from summer 
collection as well as in comparison with the autumn sampling of WBC. RBC measured values in all three seasons sampling did not show any significant differences either. Comparing the average value of the $\mathrm{Hg}$ Bin the Yorkshire breed were significant differences were found $(p<0.05)$ comparing the values from summer and autumn and also of sampling in comparison of sampling from summer and autumn $(p<0.05)$. In comparison of values of Hct significant differences were found, but only between spring and summer sampling $(p<0.01)$ between summer and autumn sampling there were no statistically significant differences. In comparison of the values of platelets there were no statistically significant differences either.

In the measured values of the Mangalitza breed (Fig. 2), WBC in the spring sampling there were no significant differences found in comparison with the values from the summer sampling, but when the summer sampling was compared with the autumn sampling then statistically significant differences were found $(\mathrm{p}<0.001)$. The average value of $\mathrm{WBC}$ in the spring collection was below the average value of WBC than in the summer collection. RBC values in all three seasons sampling showed no statistically significant differences. Comparing the average value of $\mathrm{HgB}$ in the Mangalitza breed, significant differences were found $(p<0.05)$ in comparing the values from the spring and autumn sampling. The average value of the summer sampling was lower than in the spring collection and higher than in the autumn collection. In comparison of values Hct no significant differences were found between the spring and summer sampling $(\mathrm{p}<0.05)$ as well as between the spring and the autumn sampling $(\mathrm{p}<0.001)$. In comparison of the values of Pltit was found that there were statistically significant differences similarly to the Hct between the spring and summer sampling $(p<0.01)$ and between the spring and autumn sampling $(\mathrm{p}<0.001)$.

\section{Discussion}

The quality of pig farming also contributes to a good level of health and the well-being of pigs in a breeding environment, underpinned by information about the physiological state of animals that can be found among other things, in measurement as well as various haematological parameters. A breeder receives information about changes in an organism or animal disease during the different stages of life. The poor quality of feed may affect the level of some physiological parameter values, as well as the technology of breeding and natural conditions, it also includes the effect of temperature, the season can significantly affect the physiological status of the animals. The value of individual markers can also be affected by excessive exposure to stress.
The measured values of selected hematological parameters in comparison with different breeds of pig sin the same season (Table 1) also showed statistically significant differences. In the autumn sampling from selected hematological parameters, Plt value was higher in the Yorkshire breed where other values of $\mathrm{WBC}$, $\mathrm{RBC}, \mathrm{Hg}$ Band Hct were higher in the Mangalitza breed. In comparison with the values of selected hematology parameters (Table 1) between the breeds Yorkshire and Mangalitza indifferent seasons statistically significant values were found $(p<0.001)$ in the spring and summer sampling in all examined parameters, in an autumn sampling statistically significant values were found but only in parameter RBC, Hg Band Hct. WBC and Plt did not show statistically significant values. Comparing the average values of selected haematological parameters between the breeds Yorkshire and Mangalitza we obtained the following results: Average values of WBC and Plt were higher in the Yorkshire breed than in the Mangalitza breed, average values of other parameters $\mathrm{RBC}, \mathrm{Hg}$ Band Hct were higher in the Mangalitza breed.

Rolinec et al. (2010) investigated the selected haematological parameters of pigs in early postnatal development. When we compared them with the measured values of the Yorkshire and Mangalitza breeds, these values were lower. Determined values of erythrocytes (RBC) in the blood of piglets had ad own ward trend. When we compared them with those in the Yorkshire and Mangalitza breeds these values were much lower. $\mathrm{Hg}$ B values were significantly lower. RBC values were similar in the Yorkshire and Mangalitza breeds and were also significantly higher. According to Buleca et al. (2010) measurements of haematological parameters did not show statistical significance in either case. The obtained values correspond to the total number of erythrocytes standard of physiological values for pigs. Hematocrit value in all studied groups obtained a lower limit of the physiological norm. Hemoglobin levels and Mean Corpuscular Volume (MCV) except for the period of weaning showed values identical to those of other authors (Kraft and Dürr, 2001; Doubek et al., 2003). The numbers of leukocytes in the categories of piglets and pigs for slaughter correspond with the values reported in the literature (Vrzgula and Sokol, 1987). Kraft and Dürr (2001) reported that in pigs the number of leukocytes is higher than in other species of domestic mammals (Buleca et al., 2010). In early winter, we recorded significantly higher values in the concentration of leukocytes, when compared with the end of the summer. Similarly, significant differences were found in comparison with the end of summer and winter, in this comparison Hct value was higher in winter than in summer $(\mathrm{p}<0.05)$. Comparing the monitoring of haematological parameters in summer and winter, it was found that the values of $\mathrm{RBC}, \mathrm{HgB}$, Hct and WBC were higher in winter (ChmielowiecKorzeniowska et al., 2012). 

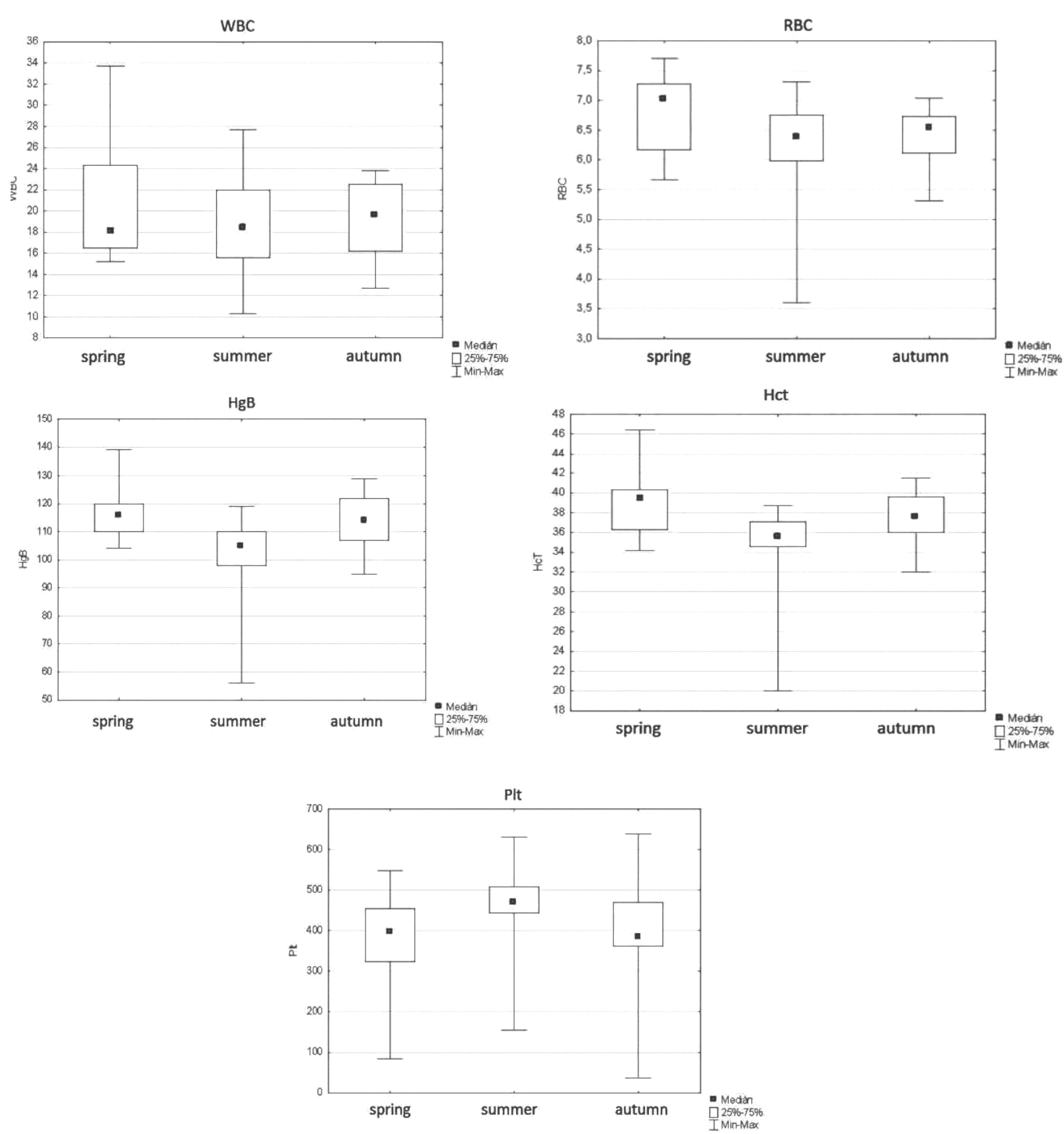

Fig. 1. Average values of White Blood Cells (WBC), Red Blood Cells (RBC), Hemoglobin (HgB), Hematocrit (Hct), Platelets (Plt) in the Yorkshire breed in the spring, summer and autumn sampling

Table 1. Comparison of the mean values of selected hematological parameters in the Yorkshire and Mangalits breeds in the spring, summer and autumn samplings (Mann Whitney-U test)

\begin{tabular}{lccrrrr}
\hline Parameter & \multicolumn{1}{c}{ Spring } & & \multicolumn{2}{c}{ Summer } & & \multicolumn{2}{c}{ Autumn } \\
$\mathrm{N}=15$ & \multicolumn{1}{c}{ Mangalitza } & \multicolumn{1}{c}{ Mangalitza } \\
$\mathrm{p}$ & $\mathbb{1} 0.0001$ & \multicolumn{1}{c}{ Yorkshire } & \multicolumn{1}{c}{0.001} & \multicolumn{1}{c}{ Yorkshire } & \multicolumn{1}{c}{0.001} & \multicolumn{1}{c}{ Yorkshire } \\
\hline $\mathrm{WBC}\left(\times 10^{9} / \mathrm{L}\right)$ & $12.65 \pm 1.210$ & $19.95 \pm 5.1500$ & $13.63 \pm 2.7200$ & $18.91 \pm 4.4400$ & $20.79 \pm 3.890$ & $19.12 \pm 3.1800$ \\
$\mathrm{RBC}\left(10^{2} / \mathrm{L}\right)$ & $8.57 \pm 0.490$ & $6.84 \pm 0.630$ & $8.22 \pm 0.5900$ & $6.24 \pm 0.9300$ & $8.51 \pm 0.260$ & $6.40 \pm 0.4500$ \\
$\mathrm{HgB}(\mathrm{g} / \mathrm{L})$ & $161.73 \pm 13.97$ & $116.40 \pm 8.7000$ & $155.80 \pm 19.630$ & $101.73 \pm 15.120$ & $147.13 \pm 7.630$ & $113.73 \pm 8.9700$ \\
$\mathrm{Hct}(\%)$ & $56.10 \pm 3.610$ & $38.89 \pm 2.9900$ & $49.31 \pm 5.6600$ & $34.74 \pm 4.6500$ & $45.93 \pm 1.430$ & $37.65 \pm 2.5200$ \\
$\mathrm{Plt}\left(\times 10^{9} / \mathrm{L}\right)$ & $186.73 \pm 53.21$ & $370.80 \pm 121.89$ & $303.20 \pm 101.34$ & $460.47 \pm 118.47$ & $337.47 \pm 99.77$ & $392.87 \pm 145.69$ \\
\hline
\end{tabular}



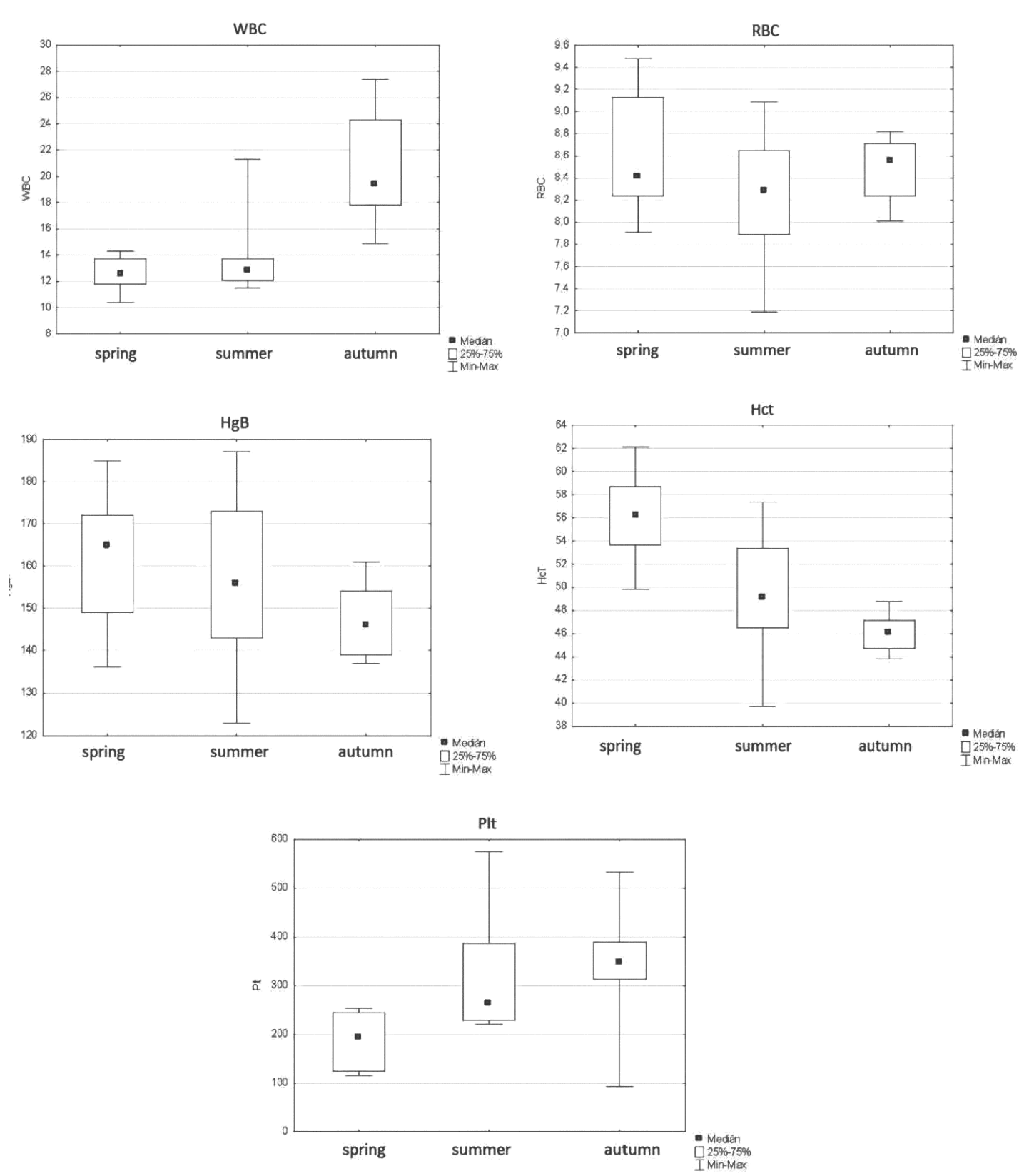

Fig. 2. Average values of White Blood Cells (WBC), Red Blood Cells (RBC), Hemoglobin (HgB), Hematocrit (Hct), Platelets (PIt) in the Mangalitza Breed in the spring, summer and autumn sampling

The measured values in the Yorkshire and Mangalitza breeds gradually increased from spring to autumn. De et al. (2013) examined selected hematological parameters in four pig breeds in India andaman wildpig, pig Nicobar andamandesi pig, Large White Yorkshire (LWY). A significantly $(\mathrm{p}<0.05)$ higher concentration of WBC, RBC and hemoglobin was measured in Andaman wild pigs compared to other breeds. There were no statistically significant differences in values of Plt between the breeds of the Andaman wild pig and large white Yorkshire, but Plt values were significantly higher in comparison with the Andaman
Nicobar wild pig and Andamandesi pig. In comparison with selected hematological parameter sit was found that the Andaman wild pig when compared to other breeds is the most adaptable to a humid climate environment and the least adaptable is the large white Yorkshire breed.

\section{Conclusion}

Haematological tests belong to important laboratory diagnostic methods. Blood composition and proportion of the components are important indicators of health and functional status of the organism. We found a gradual 
increase in the measured values of selected parameters from spring to autumn. Some average values of the parameter $\mathrm{WBC}$ and the Plt were higher in the Yorkshire breed than in the Mangalitza breed, which may be the result of different farming methods, Mangalitza are reared naturally in a wild pasture as organic live stock and Yorkshire in conventional holding and thus the difference in the development of the immune system. We assume a genetic predisposition. In some Plt values measured in summer in the Mangalitza breed and in the autumn sampling in the Yorkshire breed, the range of values from minimum to maximum was larger than it is in the literature. The nutrient animal husbandry depends on the overall health and welfare of animals. While understanding the physiological parameters of the haematological profile of these breeds and is helpful in evaluating the health of the animals and consequently, their slaughter value.

\section{Funding Information}

The study was supported by grant Kega 016PU4/2012 and partially supported by the Slovak Grant Agency for Science VEGA no. 1/1236/12.

\section{Author's Contributions}

Janka Kotosová: Substantial contribution to acquisition of the data, drafting the article, final approval of the submitted version.

Janka Poráčová: Substantial contribution to conception and design, drafting the article, final approval of the article.

Ladislav Vaško: Analysis and interpretation of the data, rewieving critically for intellectual content, final approval of the versions.

Marta Mydlárová Blaščáková: Substantial contribution to conception and design, drafting the article, final approval of the article.

Janka Vašková: Analysis and interpretation of the data, reviewing critically for intellectual content, final approval of the versions.

\section{Ethics}

The authors declare no financial/commercial conflicts of interest with the published data.

\section{References}

Barnett, J.L., P.H. Hemsworth, G.M. Cronin, E.C. Jongman and G.D. Hutson, 2001. A review of the welfare issues for sows and piglets in relation to housing. Aus. J. Agric.. Res., 52: 1-28.

DOI: $10.1071 /$ AR00057
Buleca, Jr., J. M.Húska, P. Reichel, M. Tučková and S. Mardzinová, 2010. Characteristics of energetic metabolism parameters in mangalica pig breed. Stočarstvo, 64: 107-111.

Chmielowiec-Korzeniowska, A., T. Leszek and M. Babicz, 2012. Assessment of selected parameters of biochemistry, hematology, immunology and production of pigs fattened in different seasons. Archiv. Fuer. Tierzucht, 55: 469-479.

De, K.A., A. Kundu, M.S. Kundu, J. Sunder and S. Jeyakumar, 2013. Comparative study on haematological traits of endangered Andaman wild pig and other indigenous pig breeds available at Andaman and Nicobar Islands, India. Vet. World, 6: 794-798. DOI: 10.14202/vetworld.2013.794-798

Doubek, J., 2007. The Interpretation of the basic Biochemical and Hematological Findings in Animals. 1st Edn., Brno: Noviko, ISBN-10: 80-86542-16-5, pp: 78.

Doubek, J., J. Bouda, M. Doubek and R. Vodička, 2003. Diseases of the Blood and Blood-Forming Tissues of Mammals. In: Veterinary Hematology, Doubek J., (Ed.), Brno, Noviko, pp: 177-315.

Fazekašová, D. and J. Poráčová, 1999. Fundamentals of Agricultural Production. 1st Edn., Prešovská University, Prešov. ISBN-10: 80-88886-62-0, pp: 184.

Kraft, W. and U. Dürr, 2001. Klinická Laboratórna Diagnostika Vo Veterinárnej Medicíne. 1st Edn., Hajko and Hajková, Bratislava, ISBN-10: 8088700515, pp: 365.

Lojda, V., D. Rajčok and V. Kumičík, 2008. The results of performance tests of pigs in the Slovak Republic in 2007. Bratislava: Breeding Services of the Slovak Republic.

Mlynek, J., I. Imrich and E. Mlyneková, 2012. Effect of external factors before slaughter on meat quality of pigs. Res. Pig Breeding, 6: 41-45.

Ochodnícky, D. and J. Poltársky, 2003. Sheep, Goats and Pigs. 1st Edn., Bratislava: Prírod, ISBN-10: 8007112189, pp: 104.

Rolinec, M., D. Bíro, P. Š́astný and T. Kanka, 2010. Analysis of haematological profile of piglets in early postnatal period. Acta Fytotechnica Zootechnica, 13: 40-43.

Sambraus, H.H., 2006. Atlas of Breeds of Industrial Animals: Cattle, Sheep, Goats, Horses, Donkeys, Pigs: 250 Breeds. 1st Edn., Brazda Publishing, Prague, ISBN-10: 80-209-0344-5, pp: 295.

Tančin, V., 2013. Livestock farming in marginal areas. 1st Edn., Centrum Výskumu Živočíšnej Výroby Nitra, ISBN-10: 978-80-89418-26-8, pp: 174.

Vrzgula, L. and J. Sokol, 1987. Values of metabolic profiles of tests on domestic animals and interpretation there of (in Slovak). Inštitút Výchovy a Vzdelávania Veterinárnych Lekárov, Košice. 